\title{
Study on the Preparation and Mechanical Properties of MgAlON Composites
}

DOI: 10.15255/KUI.2016.026

KUI-37/2016

Original scientific paper

Received June 26, 2016

Accepted October 17, 2016

\author{
Y.-Q. Guo* \\ Huanghe Science and Technology College, Henan Province, 450 063, P.R. China
}

\begin{abstract}
$\|$ Abstract
MgAlON composites have been prepared under nitrogen atmosphere, using Dengfeng calcined alumina $w\left(\mathrm{Al}_{2} \mathrm{O}_{3}\right)=85 \%$ and other raw material, in order to reduce the production cost and make full use of the rich bauxite resources in Henan Province. The effects of the different sintering temperature and different matrix content on the preparation and properties of $\mathrm{MgAlON}$ composites were investigated. The results indicated that: apparent porosity, linear expansion, and weight gain had increased; the gradual bulk density decreased with an increased amount of MgAlON, but the room temperature flexural strength increased; the bulk density of the specimen decreased slightly; the apparent porosity increased, room temperature flexural strength increased with the temperature; the best sintered performances of the specimen was at $1500{ }^{\circ} \mathrm{C}$. Compared with the bauxite-based MgAlON composite magnesia material, the alumina-based spinel MgAlON composite material had higher density and better strength effect of nitride.
\end{abstract}

\author{
$\|$ Keywords \\ MgAlON composites, sintering, bauxite-based MgAlON, bauxite-based spinel MgAlON
}

\section{Introduction}

MgAlON composites have been found to possess superior mechanical properties, thermal shock resistance and slag resistance, and their oxidation resistance is better than that of carbon composite refractory materials. ${ }^{1-3}$ They may replace carbon composite materials in high temperature furnaces, melting technology of ultra-low carbon steel, and more importantly, MgAlON and its composites have good application prospects in improving the quality of steel. ${ }^{4}$ Synthetic MgAlON and its composites with pure chemical raw materials have some disadvantages (high cost of raw materials, complex preparation process, high requirements for equipment, harsh process conditions, high energy consumption), so they are difficult to popularize in the practical application. ${ }^{5}$ In order to reduce the production cost and make full use of the rich bauxite resources in Henan Province, this paper examines the effects of different sintering temperature and different matrix content on preparation and properties of bauxite-based MgAlON composite.

\section{Experimental}

Experimental materials: Dengfeng calcined alumina (chemical composition's contents are shown in Table 1); high purity electro-fused magnesia $(1-3 \mathrm{~mm})$; fused magnesia alumina spinel $(\leq 1 \mathrm{~mm})$; $\mathrm{Al}$ powder $(\leq 0.088 \mathrm{~mm})$; active $\mathrm{Al}_{2} \mathrm{O}_{3}$ powder $(\leq 5 \mu \mathrm{m})$; chemically pure $\mathrm{MgO}$ $(\leq 0.04 \mu \mathrm{m})$; small amount of dextrin as raw material, and a small amount of sintering aids. The ingredient list of the experiments are shown in Table 2.

*Yanqin Guo, Master's degree in Materials Science

e-mail: 27669932@qq.com
Table 1 - Chemical components of Dengfeng bauxite

Tablica 1 - Kemijski sastav boksita Dengfeng

\begin{tabular}{c|c|c|c|c|c|c|c|c}
\hline $\begin{array}{l}\text { Chemical } \\
\text { composition } \\
\begin{array}{l}\text { Kemijski } \\
\text { sastav }\end{array}\end{array}$ & $\mathrm{Al}_{2} \mathrm{O}_{3}$ & $\mathrm{SiO}_{2}$ & $\mathrm{TiO}_{2}$ & $\mathrm{Fe}_{2} \mathrm{O}_{3}$ & $\mathrm{CaO}$ & $\mathrm{MgO}$ & $\mathrm{K}_{2} \mathrm{O}$ & $\mathrm{Na}_{2} \mathrm{O}$ \\
\hline$w / \%$ & 85.44 & 4.96 & 4.05 & 2.16 & 0.64 & 0.54 & 0.25 & 0.02 \\
\hline
\end{tabular}

Table 2 - Formulation of the specimens

Tablica 2 - Priprema uzoraka

\begin{tabular}{|c|c|c|c|c|}
\hline \multirow{3}{*}{$\begin{array}{c}\begin{array}{c}\text { Sample } \\
\text { Uzorak }\end{array} \\
\text { grain size } \\
\text { veličina zrna }\end{array}$} & \multirow{2}{*}{\multicolumn{2}{|c|}{$\begin{array}{c}\text { Aggregate /\% } \\
\text { Agregat/\% } \\
\text { MgO/MA }\end{array}$}} & \multicolumn{2}{|c|}{$\begin{array}{l}\text { Bulk material } / \% \\
\text { Rasuti materijal/\% }\end{array}$} \\
\hline & & & \multirow{2}{*}{$\begin{array}{c}\mathrm{MgO} / \mathrm{MA} \\
<0.074 \mathrm{~mm}\end{array}$} & \multirow{2}{*}{$\begin{array}{c}\mathrm{Al}(<0.074 \mathrm{~mm}) \\
- \text { bauxite } \\
(<0.088 \mathrm{~mm}) \\
-\mathrm{MgO}\end{array}$} \\
\hline & 3-1 mm & $1-0 \mathrm{~mm}$ & & \\
\hline MM1 & 45 & 15 & 20 & 20 \\
\hline MM2 & 45 & 15 & 10 & 30 \\
\hline MM3 & 45 & 15 & 0 & 40 \\
\hline JM1 & 45 & 15 & 20 & 20 \\
\hline JM2 & 45 & 15 & 10 & 30 \\
\hline JM3 & 45 & 15 & 0 & 40 \\
\hline
\end{tabular}

Notes: MM on behalf of bauxite-based MgAlON combined with MgO,

JM on behalf of bauxite-based MgAlON combined with $\mathrm{MgAl}_{2} \mathrm{O}_{4}$, MgAlON content of 1, 2, 3 respectively $20 \%, 30 \%, 40 \%$

Design scheme of weighing various powder was placed into the planetary ball mill to grind for 3 hours; aggregate was added in the ball, dry grinding 3 minutes, add- 
ed dextrin, wet mixing for 3 minutes, and then added mixed powder mixture for mixing 20 minutes. After mixing the ingredients, the strip sample was pressed into $25 \mathrm{~mm} \times 25 \mathrm{~mm} \times 125 \mathrm{~mm}$ pieces under the pressure of $150 \mathrm{MPa}$. The test pieces were put into the drying oven $\left(110{ }^{\circ} \mathrm{C}\right)$ for $24 \mathrm{~h}$, the dried test pieces were put into the high temperature GN-2003-2 $\mathrm{MoSi}_{2}$ nitriding furnace $\left(\mathrm{N}_{2}\right.$ purity of $99.99 \%$, flow rate of $0.06-0.1 \mathrm{~m}^{3} \mathrm{~h}^{-1}$ nitrogen) and heated at different temperatures for about $6 \mathrm{~h}$. After cooling of the specimens, the quality was measured with electronic balance, the rate of weight increase was calculated, nitrogen content was determined by using the national test standard, and other physical properties were tested (bulk density, porosity, compressive strength, and flexural strength at room temperature). The phase composition and microstructure characteristics of samples were analysed by SEM (JEOLJSM-5610LV), and EDS (OXFORD-6587) was used to test the microzone composition of the samples.

\section{Results and discussion}

\subsection{Effect of MgAlON content}

After sintering at $1500{ }^{\circ} \mathrm{C}$, the physical properties of the samples were measured. The results are shown in Table 3. The flexural strength of the samples at room temperature are shown in Fig. 1.

Table 3 - Physical properties of the specimens

Tablica 3 - Fizikalna svojstva uzoraka

\begin{tabular}{|c|c|c|c|c|}
\hline 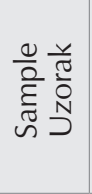 & $\begin{array}{c}\text { Apparent } \\
\text { porosity/\% } \\
\text { Prividna } \\
\text { poroznost } \\
/ \%\end{array}$ & $\begin{array}{l}\text { Density } / \mathrm{g} \mathrm{cm}^{-3} \\
\text { Gustoća } / \mathrm{g} \mathrm{cm}^{-3}\end{array}$ & $\begin{array}{c}\text { Linear } \\
\text { change } / \% \\
\text { Promjena } \\
\text { duljine } \\
/ \%\end{array}$ & $\begin{array}{c}\text { Weight gain } \\
/ \% \\
\text { Porast mase } \\
\quad / \%\end{array}$ \\
\hline MM1 & 28.40 & 2.53 & 1.74 & 0.32 \\
\hline MM2 & 31.38 & 2.41 & 1.81 & 1.06 \\
\hline MM3 & 31.88 & 2.37 & 1.98 & 1.82 \\
\hline JM1 & 23.29 & 2.69 & 0.65 & 1.60 \\
\hline JM2 & 25.31 & 2.65 & 1.09 & 2.15 \\
\hline JM3 & 25.56 & 2.63 & 1.23 & 4.12 \\
\hline
\end{tabular}

Table 3 and Fig. 1 show that with an increasing amount of MgAlON content, the volume density of the sample decreases gradually, the apparent porosity, line change rate, weight gain rate increase gradually, and the flexural strength at room temperature shows an upward trend. This indicates that the sintering properties of samples are improved with an increased quantity of MgAlON, which is mainly due to the metal aluminum nitride reaction and nitridation process of weight gain. The combination between the particles and matrix can be conducive, and thereby the density and strength of the specimens can improve, but larger volume expansion in the process affects the material influence porosity and linear change rate. ${ }^{6}$

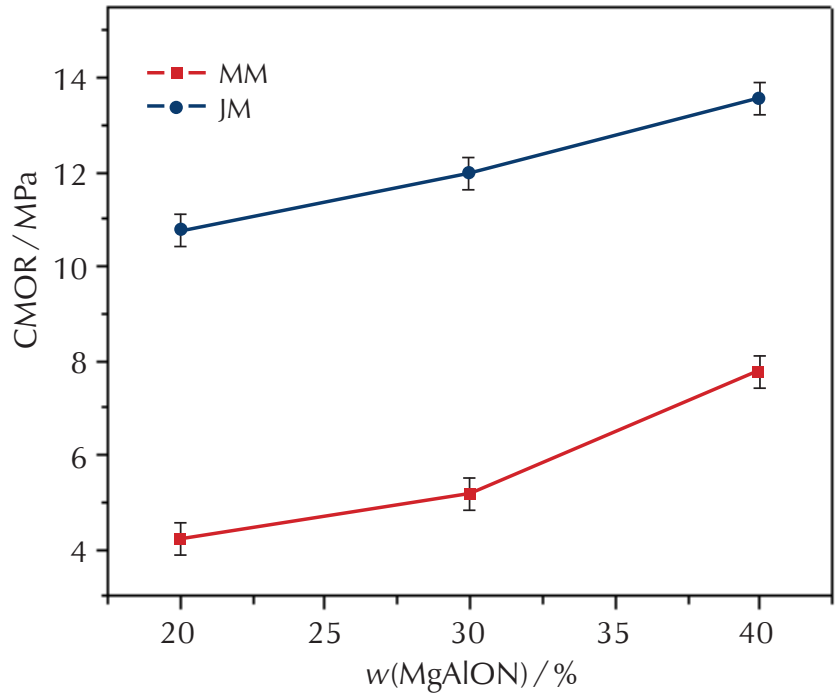

Fig. 1 - Influence of MgAlON content on the CMOR

Slika 1 - Utjecaj sadržaja MgAlON na CMOR

\subsection{Effect of sintering temperature}

MM3 samples and JM3 samples were used to test the effect of sintering temperature, and compare and analyse sintering properties and microstructure.

\subsubsection{Properties of samples at different temperatures}

The effects of sintering temperature on the sintering properties and mechanical properties of $\mathrm{MgAlON}$ composites at $1300{ }^{\circ} \mathrm{C}, 1400{ }^{\circ} \mathrm{C}$, and $1500{ }^{\circ} \mathrm{C}$ under nitrogen atmosphere were tested. The performances of the samples after sintering temperature are shown in Table 4 and Fig. 2:

Table 4 - Physical properties of the specimens at different temperature

Tablica 4 - Fizikalna svojstva uzoraka dobivenih pri različitim temperaturama

\begin{tabular}{|c|c|c|c|c|}
\hline 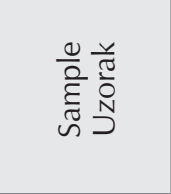 & $\begin{array}{c}\text { Apparent } \\
\text { porosity/\% } \\
\text { Prividna } \\
\text { poroznost } \\
\text { /\% }\end{array}$ & $\begin{array}{l}\text { Density } \\
/ \mathrm{g} \mathrm{cm}^{-3} \\
\text { Gustoća } \\
/ \mathrm{g} \mathrm{cm}^{-3}\end{array}$ & $\begin{array}{c}\text { Linear } \\
\text { change } / \% \\
\text { Promjena } \\
\text { duljine } \\
/ \%\end{array}$ & $\begin{array}{c}\text { Weight gain } \\
\text { rate } / \% \\
\text { Porast mase } \\
\quad / \%\end{array}$ \\
\hline MM3-1300 & 23.57 & 2.64 & 1.27 & 1.71 \\
\hline MM3-1400 & 27.19 & 2.56 & 1.73 & 1.49 \\
\hline MM3-1500 & 31.88 & 2.37 & 1.98 & 1.82 \\
\hline JM3-1300 & 23.69 & 2.65 & 0.47 & 1.74 \\
\hline JM3-1400 & 25.97 & 2.63 & 0.65 & 2.00 \\
\hline JM4-1500 & 25.33 & 2.63 & 1.23 & 4.12 \\
\hline
\end{tabular}

It may be seen from Table 4 and Fig. 2 that, during the firing process, the weight of the two samples increase, indicating 


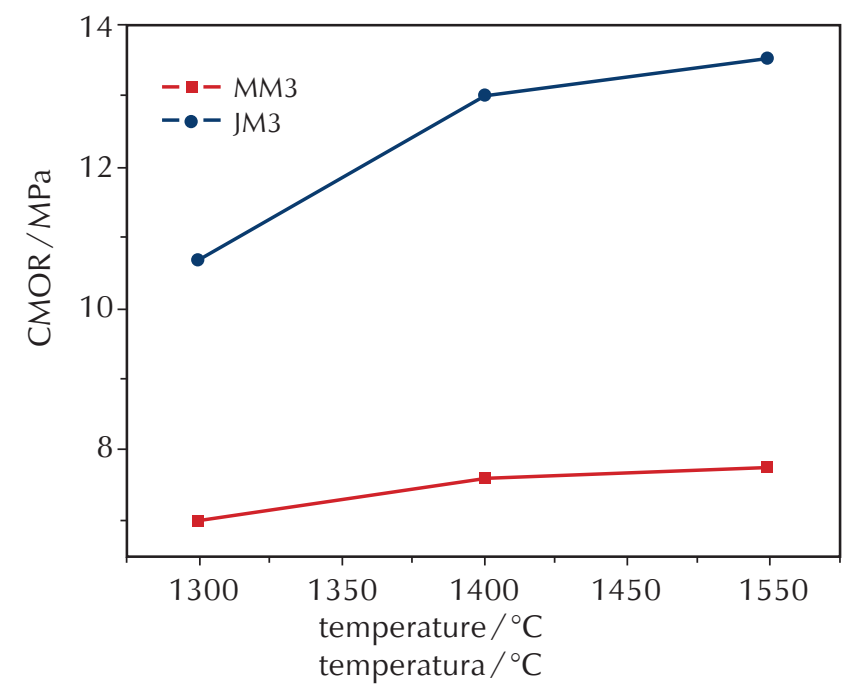

Fig. 2 - Influence of sintering temperature on the CMOR Slika 2 - Utjecaj temperature sinteriranja na CMOR

that the samples absorbed a certain amount of nitrogen in the reaction process, and the weight gain rate of $M M$ samples is significantly less than that of the JM samples. During the firing process, an expansion effect of the two samples occurred, the change rate of firing line increases with an increase in sintering temperature, and the change rate of the MM samples is larger. Therefore, the sintering properties and the nitriding effect of JM series samples are better than those of MM series samples.

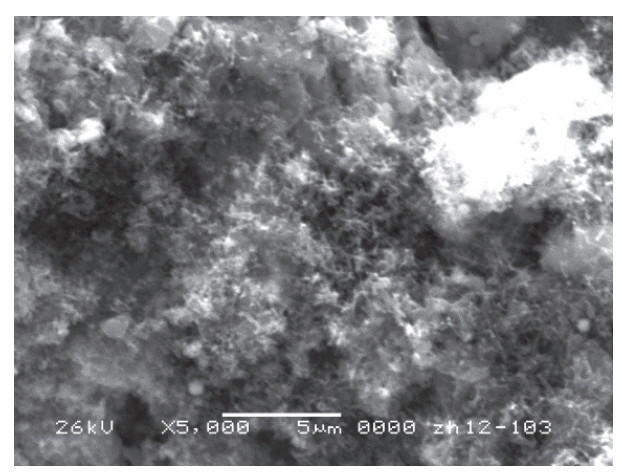

Fig. 3 - Plate-like crystals sintered at $1300{ }^{\circ} \mathrm{C}(\mathrm{MM} 3)$ Slika 3 - Pločasti kristali sinterirani na $1300^{\circ} \mathrm{C}(\mathrm{MM} 3)$

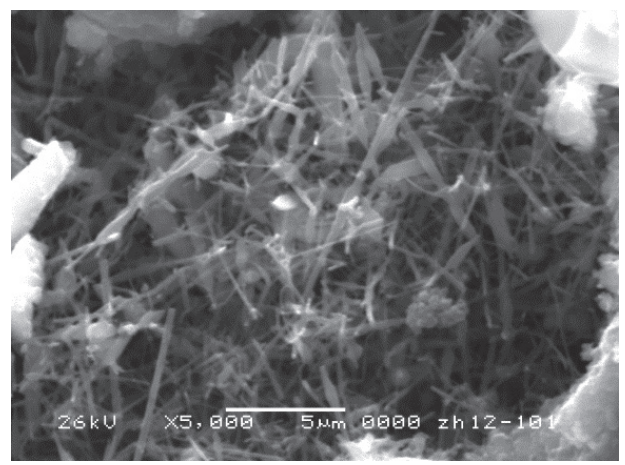

Fig. 5 - Needle-like crystals sintered at $1400{ }^{\circ} \mathrm{C}(\mathrm{MM} 3)$ Slika 5 - Igličasti kristali sinterirani na $1400{ }^{\circ} \mathrm{C}$ (MM3)
In addition, with the increase in sintering temperature, the volume density of the samples decrease slightly, and the apparent porosity and room temperature flexural strength increase slightly. The change in bulk density and apparent porosity of JM samples is smaller than those of MM samples, so the strength of JM samples increases greatly.

With the increase in sintering temperature in the experimental range, the nitriding effect of the samples was good, and density and strength of the material had improved, especially at $1500{ }^{\circ} \mathrm{C}$. Compared with the MM samples, the JM samples had a better effect on the nitriding, density, strength of the material, and the volume stability of the sintering process.

\subsubsection{Microstructure of samples at different temperatures}

At $1300{ }^{\circ} \mathrm{C}$, as may be seen from Figs. 3 and 4 , the aggregated large particles are formed by the reaction of small grains in the matrix. The small grain size of the matrix is mostly $300-600 \mathrm{~nm}$, the surface of those grains is rough, and their shape is irregular. The EDS analysis shows that there are small grains of nitrogen (chemical composition in amount fraction: $\mathrm{Al} 64.76 \%$, O $21.21 \%, \mathrm{~N} 10.09 \%$, Mg $3.94 \%$ or Al $48.06 \%$, O $44.10 \%$, N $5.23 \%$, Mg $2.62 \%$ ), but there are also small grains that still have no nitrogen. Therefore, it may be concluded that there are some parts of the aluminum in the sample that cannot completely nitride under the temperature conditions. Since the nitride product crystal size is smaller, it is easy to build clusters and a more complicated microstructure of materials.

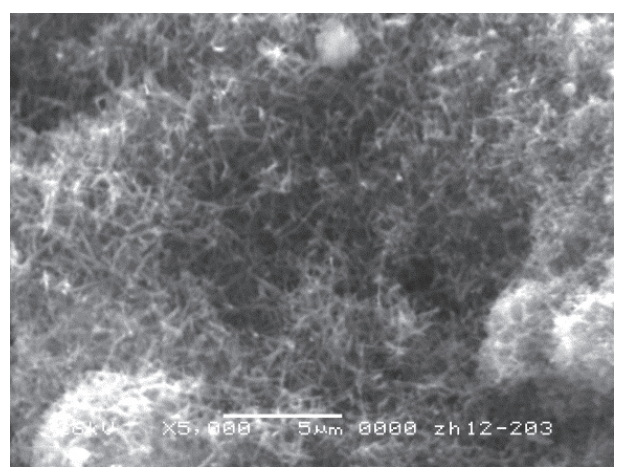

Fig. 4 - Plate-like crystals sintered at $1300{ }^{\circ} \mathrm{C}(J M 3)$ Slika 4 - Pločasti kristali sinterirani na $1300{ }^{\circ} \mathrm{C}(J M 3)$

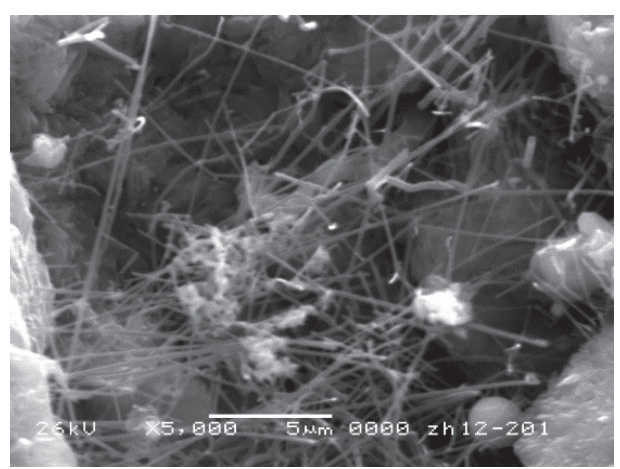

Fig. 6 - Needle-like crystals sintered at $1400{ }^{\circ} \mathrm{C}(\mathrm{JM} 3)$ Slika 6 - Igličasti kristali sinterirani na $1400{ }^{\circ} \mathrm{C}(J M 3)$ 


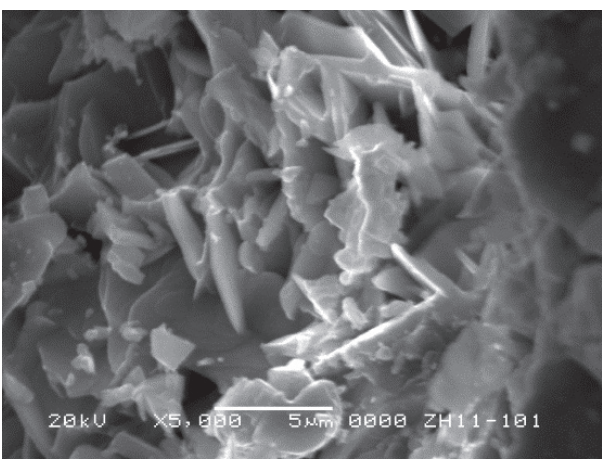

Fig. 7 - SEM photograph of MM3 sintered at $1500{ }^{\circ} \mathrm{C}$ Slika 7 - SEM-fotografija uzorka MM3 sinteriranog pri $1500{ }^{\circ} \mathrm{C}$

At $1400{ }^{\circ} \mathrm{C}$, as may be seen from Figs. 5 and 6, the microstructure of the fracture surface shows that the small grains formed by the reaction in the matrix closely surround the aggregate. Energy spectrum analysis data shows that the samples' nitriding degree is high, the metal aluminum basically is completely nitrided, particles are slightly larger, but still have a large number of submicron particles, and the size is more uniform.

As may be seen from Figs. 7 and 8 , at $1500{ }^{\circ} \mathrm{C}$, the aggregated large particles are also closely surrounded by the small grains formed in the matrix, there are many small pores around the grains, and many whiskers and flake crystals in the pores. The shape of completely formed crystals is octahedron or plate-like. Therefore, there are more gas phase reactions in the firing process. The size of small particles increased significantly, and is more uniform. ${ }^{8}$ The EDS analysis shows that the grain nitrogen content in the sample is higher, there is more nitride, and the trace element $\mathrm{Si}$ and Ti can be dissolved in the nitride, so the harmful effect is reduced.

The microstructure analysis of the above samples suggests that nitrided samples level is relatively low, grain size is small, crystal growth rate is low and easy to build clusters, and at the same time, there are many whiskers in the pores, and the structure is more complex at $1300{ }^{\circ} \mathrm{C}$ or at $1400{ }^{\circ} \mathrm{C}$. After the firing of the sample at $1500{ }^{\circ} \mathrm{C}$, the metal aluminum nitride is more complete, and the nitrogen content of the product is higher, the particle diameter is larger, the size of the particle is uniform, the development of grains in JM samples is relatively complete, the generated grain size is several microns, and there are a variety of crystal structures and crystals crossing with each other. Therefore, according to the results of microstructure analysis, the test results at $1500{ }^{\circ} \mathrm{C}$ are the best.

\subsection{Microstructure and energy spectrum analysis of the sample after sintering}

\subsubsection{Bauxite-based MgO-MgAlON sample}

Fig. 9 shows a fracture morphology of the specimen at $1500{ }^{\circ} \mathrm{C}$, and Fig. 10 shows an internal crystalline structure sample. The results of spectrum analysis are shown in Table 5.

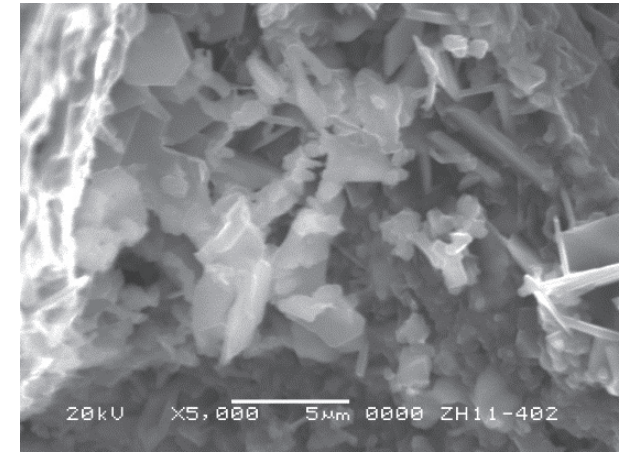

Fig. 8 - SEM photograph of JM3 sintered at $1500{ }^{\circ} \mathrm{C}$ Slika 8 - SEM-fotografija uzorka JM3 sinteriranog pri $1500{ }^{\circ} \mathrm{C}$

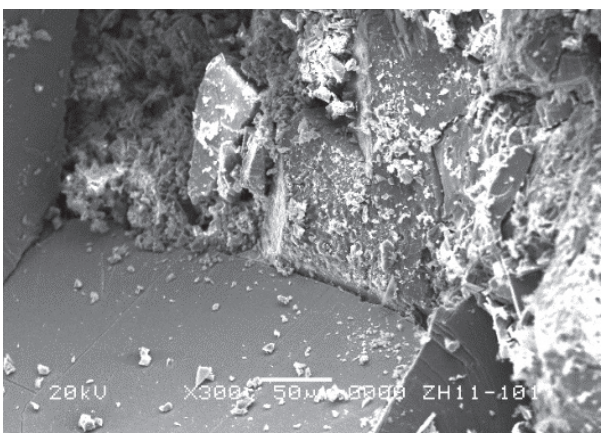

Fig. 9 - Micrograph of fracture surface of specimen Slika 9 - Mikrografija površine loma uzorka

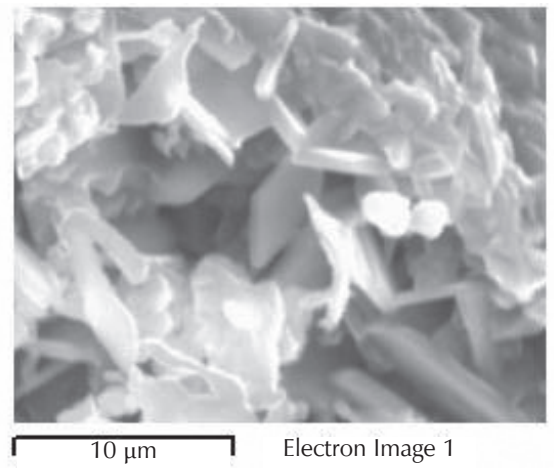

Fig. 10 - Plate-like crystals of specimen Slika 10 - Pločasti kristali uzoraka

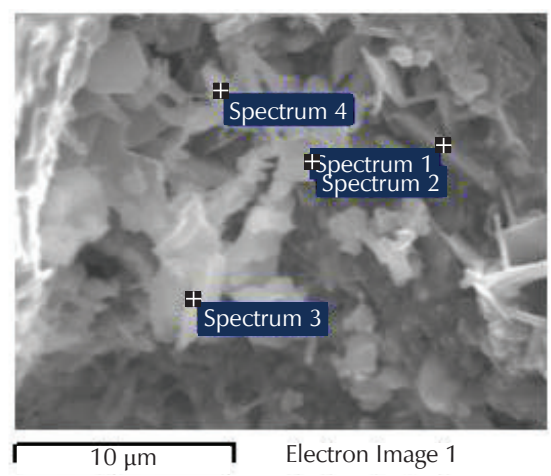

Fig. 11 - Micrograph of microcrystals of specimen Slika 11 - Mikrografija mikrokristala uzorka 
Table 5 - EDS analysis results in Fig. 11

Tablica 5 - Rezultati analize EDS-om prema slici 11

\begin{tabular}{l|c|c|c|c}
\hline \multirow{2}{*}{$\begin{array}{l}\text { Location of analysis } \\
\text { Mjesto analize }\end{array}$} & \multicolumn{4}{|c}{ w/\% } \\
\cline { 2 - 5 } Spectrum1 & $\mathrm{N}$ & $\mathrm{O}$ & $\mathrm{Mg}$ & $\mathrm{Al}$ \\
\hline Spectrum2 & 17.96 & 17.53 & 4.28 & 60.23 \\
Spectrum3 & 18.63 & 26.74 & 4.46 & 50.18 \\
& 23.09 & 25.21 & 4.23 & 47.47 \\
Spectrum4 & & & & \\
\hline
\end{tabular}

Fig. 9 indicates that the magnesium oxide large particles are formed by the reaction of small grains in the matrix of uniform size, ${ }^{4}$ many small pores are generated during nitriding reaction, and there are many whiskers and flake crystals formed in the pores (Figs. 10 and 11), which indicates that there are more gas phase reactions in the firing process. The size of small particles is slightly larger than that of the alumina-based reaction sintered samples, and the particle size is more uniform. The EDS analysis in Table 5 shows that the nitrogen content of these small grains was between $17.96 \%$ - $26.91 \%$, which was higher than that of the oxide-based materials $(16.53 \%-17.69 \%)$ in the literature. $^{7}$ The reason perhaps being that the impurities in bauxite are beneficial to the rate increase in metal aluminum nitride, and promote grain growth and development, thus improving the nitrogen content. Therefore, compared with the oxide-based samples, the bauxite samples nitriding effects and sintering properties are better.

\subsubsection{Bauxite-based $\mathrm{MgAl}_{2} \mathrm{O}_{4}-\mathrm{MgAlON}$ sample}

The fracture surface of SEM sample at $1500{ }^{\circ} \mathrm{C}$ is shown in Fig. 12, and the energy spectrum analysis is shown in Fig. 13 and Table 6.

Table 6 - EDS analysis results in Fig. 13

Tablica 6 - Rezultati analize EDS-om prema slici 13

\begin{tabular}{c|c|c|c|c}
\hline \multirow{2}{*}{$\begin{array}{c}\text { Location of analysis } \\
\text { Mjesto analize }\end{array}$} & \multicolumn{5}{|c}{$w / \%$} \\
\cline { 2 - 5 } Spectrum2 & 22.44 & 15.02 & 15.88 & 46.66 \\
Spectrum4 & 26.68 & 16.02 & 16.33 & 40.97 \\
\hline
\end{tabular}
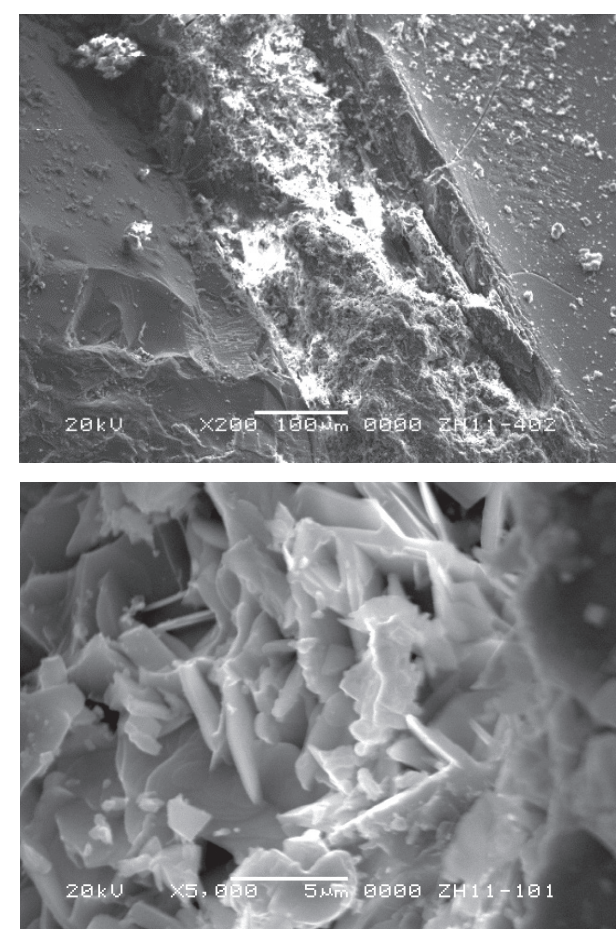

Fig. 12 - Micrograph of fracture surface of specimen Slika 12 - Mikrografski snimak površine loma uzorka

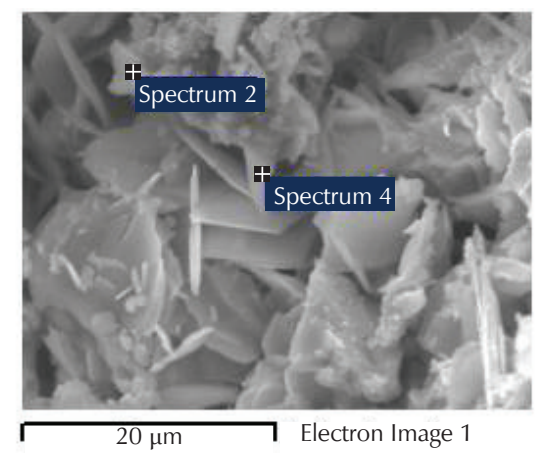

Fig. 13 - Plate-like crystals of specimen Slika 13 - Pločasti kristali uzorka

Fig. 12 indicates that the grain size and binding state of the JM and MM samples are roughly the same. MA large particles in the sample were also closely surrounded by the reaction of the MgAlON particles in the matrix. The combination of the large particles and the matrix were denser, and the obvious dividing line could not be seen. The grain samples are a few microns in size. There is a variety of crystals cross combination structure favourable to improve the strength of the material (Fig. 13). The energy spectrum analysis data in Table 6 shows that the grain nitrogen content in the sample is higher; there is more nitride than in the bauxite-based MgO-MgAlON samples. 


\subsection{Performance of alumina-based MgAlON composites and bauxite-based MgAlON composites}

\subsubsection{Physical properties of alumina and alumina-based} matrix composites

The test samples fired in a nitrogen atmosphere at $1500{ }^{\circ} \mathrm{C}$, and the sintering performance of the sintered samples are shown in Table 7.

Table 7 - Physical properties of the specimens

Tablica 7 - Fizikalna svojstva uzoraka

\begin{tabular}{|c|c|c|c|c|c|}
\hline 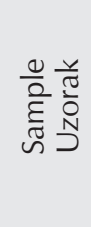 & $\begin{array}{c}\text { Weight } \\
\text { gain /\% } \\
\text { Porast } \\
\text { mase } \\
/ \%\end{array}$ & $\begin{array}{c}\text { Linear } \\
\text { change } \\
/ \% \\
\text { Promjena } \\
\text { duljine } \\
/ \%\end{array}$ & $\begin{array}{l}\text { Density } \\
/ \mathrm{g} \mathrm{cm}^{-3} \\
\text { Gustoća } \\
/ \mathrm{g} \mathrm{cm}^{-3}\end{array}$ & $\begin{array}{c}\text { Apparent } \\
\text { porosity } / \% \\
\text { Prividna } \\
\text { poroznost } \\
/ \%\end{array}$ & $\frac{\sum_{j}^{\infty}}{\sum_{j}^{0}}$ \\
\hline $\mathrm{AMM}$ & 1.82 & 1.82 & 2.66 & 23.91 & 10.12 \\
\hline $\mathrm{BMM}$ & 0.32 & 1.98 & 2.53 & 28.40 & 7.76 \\
\hline AJM & 4.10 & 0.96 & 2.74 & 22.25 & 19.37 \\
\hline BJM & 1.60 & 1.23 & 2.69 & 23.29 & 13.54 \\
\hline
\end{tabular}

Note: AMM represents the alumina-based MgAlON combined $\mathrm{MgO}$, $\mathrm{BMM}$ represents bauxite-based $\mathrm{MgAlON}$ combined $\mathrm{MgO}$, AJM represents alumina-based MgAlON binding $\mathrm{MgAl}_{2} \mathrm{O}_{4}$, BJM represents bauxite-based MgAlON binding $\mathrm{MgAl}_{2} \mathrm{O}_{4}$,

Table 7 indicates that compared with the oxide-based composite material, bauxite-based composites have a larger porosity rate, smaller volume density, and lower strength at room temperature. This may be due to the presence of impurities in the bauxite. Trace impurities can be beneficial for the reduction and nitridation of the bauxite-based MgAlON composites.

\subsubsection{High temperature mechanical properties of alumina-based samples and bauxite-based samples}

The mechanical properties of bauxite-based composites at high temperature were tested using the same method with alumina-based samples, and the high temperature mechanical properties of the two samples were compared. The results are shown in Fig. 14.

As may be seen from Fig. 14, the variation curve of MOR-T bauxite samples and alumina-based samples are consistent. There is a peak strength at a certain temperature, and then, as temperature increases, the strength starts to decline. Compared with the same aggregate, under the same temperature, the high temperature alumina specimen flexural strength is slightly higher than that of the bauxite-based samples. However, since the bauxite-based sample nitridation sintering structure is not compact enough, secondary sintering phenomenon arises as the flexural strength of test specimens at high temperature, thus the bauxite samples high temperature strength increase rate is greater. ${ }^{9} \mathrm{BMM}$ sample strength increases slowly before $1000{ }^{\circ} \mathrm{C}$, and

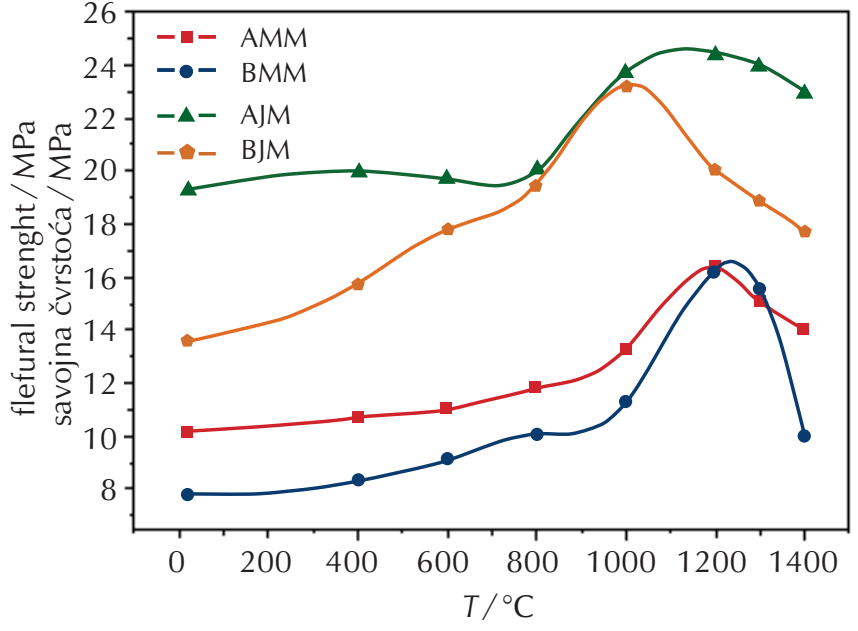

Fig. 14 - MOR-T curves of the alumina-based and bauxite-based specimens

Slika 14 - Savojna čvrstoća uzoraka na bazi aluminijeva oksida i boksita

when the temperature is higher than $1000^{\circ} \mathrm{C}$, the strength increases rapidly. The maximum value of the rapid strength increase is at $1200{ }^{\circ} \mathrm{C}$, and the average strength increases about $150 \%$ compared to room temperature. The strength of the maximum temperature point at $1400{ }^{\circ} \mathrm{C}$ is less than that at $1200{ }^{\circ} \mathrm{C}$, but it is still $30 \%$ higher than at room temperature. The strength of BJM sample increases before $800^{\circ} \mathrm{C}$, the maximum strength of the sample is at $1000{ }^{\circ} \mathrm{C}$, and the strength is increases by approximately $75 \% \mathrm{com}-$ pared to room temperature.

The composition, structure, and high temperature mechanical properties of the sintered materials of $\mathrm{Al}_{2} \mathrm{O}_{3}-\mathrm{SiO}_{2}-$ $\mathrm{ZrO}_{2}$ system were studied by academician X. C. Zhong. ${ }^{1-11}$ It was concluded that the mechanical behaviour of the material at different temperatures could be divided into three stages. The three stages represent the typical characteristics of the high temperature mechanical behaviour of the refractory materials containing liquid phase sintering: 1. Elastic deformation stage: the stress-strain curve is a straight line. Under long-term stress, the material does not produce creep, high-strength, and brittle fracture. The fracture surface of the sample is compact and smooth, which belongs to a transgranular fracture mode. 2. Plastic deformation stage: stress-strain curves deviate from a straight line. Under long-term stress, material creep phenomenon is significant, strength begins to decline, the fracture is a quasi-ductile, and the fracture is divided into smooth and rough areas, which is a mixed type of intergranular fracture. 3. Viscous flow stage: the stress-strain curve is significant and the amount of permanent deformation is large. Under the action of stress, the creep rate increases sharply, the strength becomes minimal, the fracture is a ductile, and the fracture surface is rough, which belongs to the intergranular fracture. There are two types of fracture strength with temperature changes: type I corresponds to the polycrystalline material, which is characterized by a peak value at a certain temperature. For the materials such as corundum mullite, the peak value of the strength curve is $800{ }^{\circ} \mathrm{C}$. Type II generally corresponds to 
the single crystal material, which characteristic is that the strength remains unchanged at low temperature range. When the temperature is higher than the transition temperature, the strength gradually decreases. Therefore, pure corundum material strength began to decline after $800{ }^{\circ} \mathrm{C}$. The reasons for the emergence of two kinds of curves are residual internal stress in the samples and microcrack formation and elimination, high temperature grain boundary non-crystalline phase and glass phase softening.

From the experimental results, the two series of MOR-T curves belong to the type I, proposed by academician $X$. C. Zhong. This is because the MgAION bonded magnesia composite materials are polycrystalline materials, and the phase equilibrium and the stress distribution of the material in the process of long-time thermal insulation are more balanced. During the cooling process, the thermal expansion coefficient of each phase is of larger difference between the material and the existence of residual stress, and even cracks have an impact on the strength of the material.

Fig. 14 indicates that at the same temperature, the strength of the BMM sample was lower than that of the BJM sample. The lower strength of the sample was 6-8 MPa, and the maximum strength temperature of $\mathrm{BMM}$ was $1200{ }^{\circ} \mathrm{C}$, while the maximum strength of BJM was $1000{ }^{\circ} \mathrm{C}$. There are two reasons for this: 1 ) The large porosity of BMM samples exists, which causes low sintering performance and low strength; 2) The reaction of MgAION transparent crystal phase is different, and the impurity phase exists. During the cooling process, the thermal expansion coefficient of each phase is greatly different, which causes the residual stresses and cracks in the material, so the strength of the material is relatively low, but the temperature of the microcrack bridging improves.

\section{Conclusion}

(1) With the increase in MgAlON content, the volume density of the sample decreases, the apparent porosity, lenght change, and weight gain increase gradually. The room temperature bending strength has an upward trend. JM samples nitriding effect is better, they also have high density and strength.

(2) With the increase in sintering temperature, the volume density of the samples decreases slightly, the apparent porosity and the bending strength increases gradually with the temperature.

(3) Bauxite-based sample sintering properties and mechanical properties at room temperature were lower than those of the alumina-based composites. However, the difference is small, so it can replace the use of alumina-based composite materials, in order to save production costs.

(4) The $\mathrm{MgO}-\mathrm{MgAl}_{2} \mathrm{O}_{4}-\mathrm{MgAlON}$ system MOR-T curves of samples belongs to type I curve. Strength at high temperature $\left(\leq 1400{ }^{\circ} \mathrm{C}\right)$ was higher than the strength at room temperature; intensity peak temperature of the material is $1200{ }^{\circ} \mathrm{C}$.
(5) Using the same kind of aggregate sample, the high temperature flexural strength of the alumina-based sample was slightly higher than that of the bauxite-based sample at the same temperature.

\section{ACKNOWLEDGEMENTS}

Henan Province Department of Education Science and Technology Research Key Project, THE Project Number: 16A430019.

\section{List of abbreviations and symbols Popis kratica i simbola}

CMOR - compressive modulus of rupture at room temperature - tlačna čvrstoća na sobnoj temperaturi

MA - magnesium aluminium oxide, spinel, $\mathrm{MgAl}_{2} \mathrm{O}_{4}$ - magnezijev aluminijev oksid, spinel, $\mathrm{MgAl}_{2} \mathrm{O}_{4}$

MOR-T - modulus of rupture with temperature - savojna čvrstoća ovisna o temperaturi

w $\quad-$ mass fraction, $\%$ - maseni udjel, \%

\section{References}

\section{Literatura}

1. T. M. Hartnett, S. D. Bernstein, E. A. Maguire, R. W. Tustison, Optical properties of AlON(aluminum oxynitride), Infrared Phys. Technol. 39 (1998) 203-211, doi: http://dx.doi. org/10.1016/S1350-4495(98)00007-3.

2. R. M. Sova, M. J. Linevsky, M. E. Thomas, F. F. Mark, High-temperature infrared properties of sapphire, AION, fused silica, yttria, and spinel, Infrared Phys. Technol. 39 (1998) 251261, doi: http://dx.doi.org/10.1016/S1350-4495(98)00011-5.

3. X. C. Zhong, Looking Ahead - A New Generation of High Performance Refractory Ceramics, a specially invited report in the World Refractory Congress in Singapore, 2002.

4. X. C. Zhong, Strategic thinking on the development of magnesia refractories China, Silicate Bullet. 25 (3) (2006) 91-95.

5. A. Granon, P. Goeuriot, F. Thevenpot, Reactivity in the $\mathrm{Al}_{2} \mathrm{O}_{3}-\mathrm{AlN}-\mathrm{MgO}$ system. The MgAlON Spinel Phase, J. Europ. Ceram. Soc. 13 (1994) 365-370, doi: http://dx.doi. org/10.1016/0955-2219(94)90012-4.

6. D. Y. Yang, X. R. Guo, X. C. Zhong, Preliminary Study On $\mathrm{MgO} \cdot \mathrm{Al}_{2} \mathrm{O}_{3}$ Spinel Fiber, Proc, UNITECR2003 Congress, Osaka, Japan, pp. 162-164

7. D. Y. Yang, H. Y. Zhang, X. C. Zhong, Study on preparation and mechanical property of $\mathrm{MgO}-\mathrm{MgAl}_{2} \mathrm{O}_{4}-\mathrm{MgAlON}$ composites, Refractory 40 (1) ( 2006) 12-15.

8. D. Y. Yang, X. R. Guo, X. C. Zhong, Preliminary Study on $\mathrm{MgO} \cdot \mathrm{Al}_{2} \mathrm{O}_{3}$ Spinel Fiber, Proc, UNITECR2003 Congress, Osaka, Japan, pp. 162-164.

9. Y. Q. Guo, H. Y. Zhang, Study on Preparation and properties of bauxite based MgAlON Composites, Bullet. Chinese Ceram. Soc. 34 (8) (2015) 2163-2166. 
10. W. B. Zhong, W. C. Li, X. C. Zhong, Microstructure and Mechanical Properties of $\mathrm{O}^{\prime}-$ Sialon- $\mathrm{ZrO}_{2}$ Composites. Refractories research by Zhong Xiangchong, Henan Sci. Technol. Press 1 (2001) 309-320.
11. T. S. Li, Study on Corundum mullite-high temperature mechanical properties of silicon carbide composites and thermal shock resistance, Beijing University of Technology, PhD thesis, 1990.

\section{SAŽETAK \\ Priprema i mehanička svojstva mješavina MgAlON \\ Yanqin Guo}

Da bi se smanjili troškovi proizvodnje i iskoristili izvori sirovina, pripravljeni su kompoziti MgAION u atmosferi dušika od kalciniranog aluminijeva oksida. Proučen je utjecaj sastava i temperature sinteriranja na kompozitni materijal. S količinom MgAION povećavaju se prividna poroznost, linearna ekspanzija i porast mase. Smanjuje se gustoća materijala, ali raste savojna čvrstoća. S temperaturom sinteriranja pada gustoća, a rastu prividna poroznost i savojna čvrstoća. Najbolji rezultati postignuti su sinteriranjem pri $1500{ }^{\circ} \mathrm{C}$. Kada je kao sirovina upotrijebljen aluminijev oksid, kompozit je imao veću gustoću i pokazivao pozitivniji učinak nitrida od kompozita baziranog na boksitu.

Ključne riječi

Kompoziti MgAlON, sinteriranje, MgAlON pripravljen od boksita

Huanghe Science and Technology College,

Henan Province, 450063

Izvorni znanstveni rad

Kina

Prispjelo 26. lipnja 2016.

Prihvaćeno 17. listopada 2016. 